胆管空腸吻合部良性狭窄に対しメタリックステント留置後, 再狭窄をきたし再吻合術を施行した 1 例

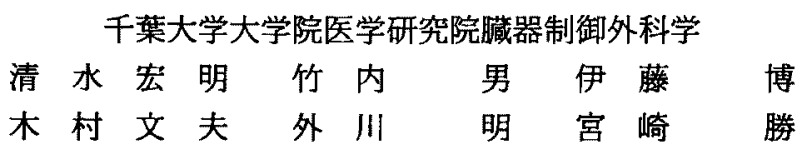

われわれは, 胆管空腸吻合術後の吻合部狭乍に対して expandable metallic stent (EMS) が留置され，その 7 年後のステント閉塞に対し，外科的治療を施行した 1 例を 経験したので報告する. 症例は48歳, 女性. 主訴は発熱, 黄疸. 前医にて先天性総胆管 㹡張症の診断にて胆管切除, 胆管空腸吻合術を施行, その 1 年後に吻合部狭窄を発症し 再吻合術を施行したが, 術後再び狭窄をきたしたため, EMS を留置した。 以後, 胆管炎 症状を繰り返していたが, EMS 留置 7 年後に急性閉塞性化膿性胆管炎となり PTBD 施 行し，ステント部での胆管閉塞を認め当科紹介となった。当科にて PTCSにて癌合併な しを診断後, 開腹にて胆管空腸吻合部を切開し EMS を除去, さらに吻合部とその肝側の 肥厚した胆管を切除し, 肝門部にて胆管空腸再吻合術を施行した. RTBDステントチュ 一ブは再狭窄予防の目的で術後 6 力月で抜去した，術後17力月現在経過良好である.

真引用語：良性胆道狭㺘, expandable metallic stent, 胆管空腸吻合

\section{緒 言}

胆道ステンティングは現在多くの施設で行われてお り, 最近ではステントの種類も豊富になり個々の症例 に合わせて選択できるようになってきている1”。しか しながら一方ではステント閉塞・逸脱などの合併症も あり末だ多くの問題点が残されている゙．特に expan. dable metallic stent (EMS) は一般的に手術以外では 回収や交換が困難であり，また長期的にはステント閉 塞をきたすことが多く良性胆管狭窄に対しての使用は 十分に慎重であるべさであるとされている2)-4). 今回 われわれは先天性総胆管拡張症術後の胆管空腸吻合部 狭窄に対してEMSが留置されその 7 年後にステント 部ての胆道閉塞をきたした症例に対し，外科的治療を 施行した 1 例を経験したのて若干の文献的考察を加え て報告する。

\section{症例}

症例：48歳，女性.

主訴：発熱, 黄㾝.

2003 年 2 月 24 日受付 2003 年 5 月 29 日採用 〈所属施設住所〉

テ260-0856 千葉市中央区亥蔂 $1-8-1$
既往歴：28歳時に虫垂切除，35歳時に帝王切開.

現病歴：前医にて先天性総胆管㹡張症の診断のもと 1993年 6 月, 胆管切除, 胆管空腸吻合術を施行し，以 後外来経過観察していた. 1994年 6 月に再び，黄疸を 発症し，経皮経肝胆道ドレナージ (PTBD) を施行し たところ胆管空腸吻合部に狭管を認めたため, 開腹に て胆管空腸再吻合術を施行した．しかしながら，術後 の RTBD 造影にて吻合部に再び高度狭窄像を認め, 胆管空腸吻合部に EMS (Wallstent ${ }^{\circledR}$ )を留置した。 その後は年に 2 回程度の胆管炎症状を認めるもの, 抗 生剤投与による保存的治療にて軽快していた。2001年 7 月, $40^{\circ} \mathrm{C}$ の発熱々黄疸 (T-Bil $\left.8.7 \mathrm{mg} / \mathrm{dl}\right)$ を伴う閉 塞性化膿性胆管炎を発症し, 前医入院. PTBD を施行 したところ, EMS 部での胆管閉塞を認め, 精査・加療 目的で2001年 8 月, 当科紹介入院となった。

入院時現症：腹部正中および右下腹部に手術痕を認 め，また上腹部正中より PTBDチューブが留置されて いた。

入院時検查所見 : 前医での PTBD 後のため, 白血球 $9,000 / \mu 1$, CRP $0.8 \mathrm{mg} / \mathrm{dl}, \mathrm{T}-\mathrm{Bil} 0.7 \mathrm{mg} / \mathrm{dl}$, GOT 14 IU/1, GPT 11IU/1, ALP 354IU/1, $\gamma$-GTP 79IU/1 と 㷋症反応，黄疸，肝機能障害は改善していた。また， 


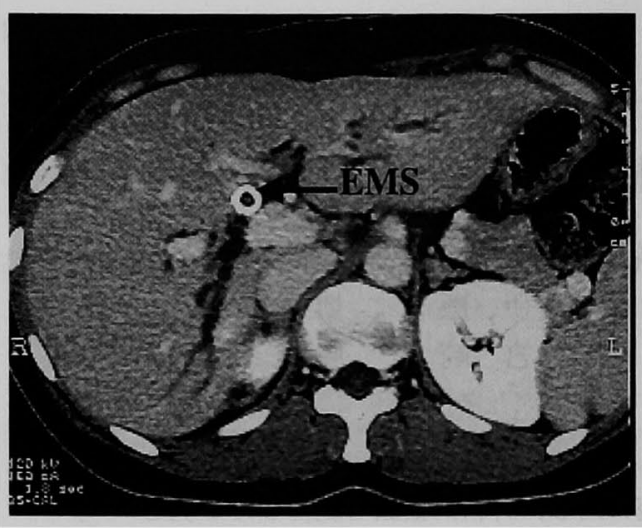

図 1 腹部 CT 所見 : 左右の肝内胆管拡張を認め, ま た EMS (矢印) は胆管空腸吻合部より肝門部まで 及んでいた。

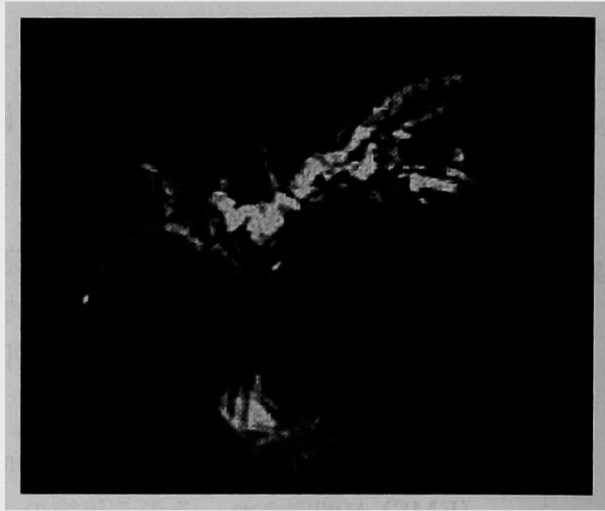

図 2 MRCP 所見：肝門部にて胆管の高度狭窄 を認め,また右後区域胆管枝は, 左, 右前区域 胆管分忮部のやや下流側より独立分岐してい た.

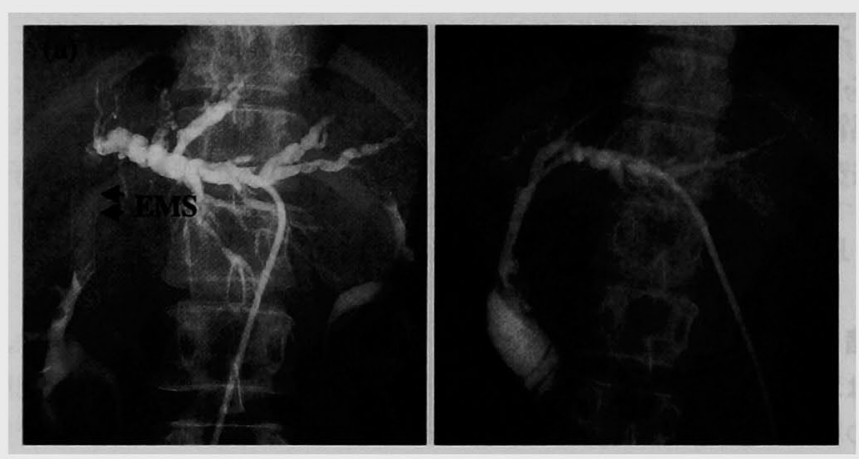

図 3 a 内癄化前 PTBD 造影所見：B3 より挿入されたPTBD チ ユーブよりの造影では EMSの肝側端において胆管閉塞を認めた.

b 挙上腸管内人内淙化後の PTBD 造影所見：举上腸管への 内瘦化後の造影では EMS の肝側端はちょうど左右胆管合流部ま で及び, EMS 部に高度狭寉像を認めた。そのため, 左側より内瘦化 された PTBDチューフよりの造影では右側胆管はわずかに造影さ れるのみであった。

CEA は $1.4 \mathrm{mg} / \mathrm{dl}, \mathrm{CA} 19-19$ は $24.8 \mathrm{mg} / \mathrm{dl}$ と正常範囲 内であった。

腹部 CT 所見 : 左右の肝内胆管拡張を認め,また EMS は胆管空腸吻合部より肝門部まで及んでいた

(図 1 ).

MRCP 所見 : 肝門部にて胆管の高度狭窄を認めた。 また右後区域胆管枝は，左，右前区域胆管分岐部のや や下流側より独立分岐していた（図2）.

PTBD 造影所見：B3より挿入されたPTBDチュ 一フの挙上腸管への内瘦化前の造影では EMS の肝側 端において胆管閉塞を認めた(図 3 a). 内㿉化後の造
影では EMS の肝側端はちょうど左右胆管合流部まて 及び, EMS 部に高度狭窄像を認めた。そのため, 左側 より内瘦化された PTBDチューブよりの造影では右 側胆管はわずかに造影されるのみであった（図 3 b).

PTCS 所見：EMS の内腔は肝側端より全周性に炎 症性肉芽組織で占められており，これが狭窄の原因と 考えられた。ステント内腔のメッシュ構造は全く観察 されなかった。狭窄部からの PTCS 下の生倹で悪性細 胞は認めなかった（図4).

血管造影：肝動脈造影・経動脈性門脈造影ともに異 常所見認めなかった. 


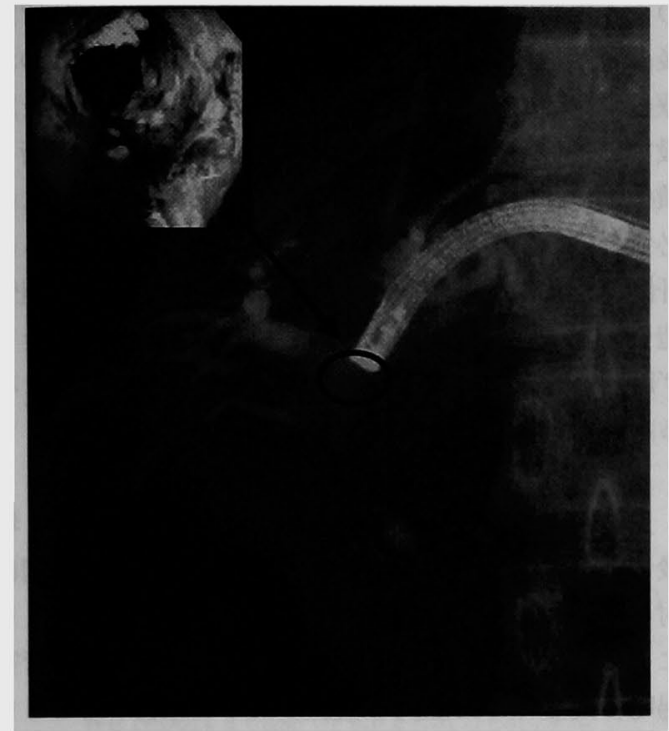

図4PTCS 所見：EMSの肝側端の肉芽組織を認 め,これが狭窄の原因と考えられた．EMS内腔の メッシュ構造は全く観察されなかった.また，右後 区域胆管枝は独立分岐で左, 右前区域胆管分岐部の やゃ下流側のステント内へ直接開ロしていた。
以上より，胆道 EMS 留置後のステント部での良性 胆道狭窄と診断し，2001年 9 月に手術を施行した。

手術所見：肝門部を中心に癒着が高度であったが, 胆管空腸吻合部を露出すると胆管は炎症性に肥厚し EMS の弾性を触知した（図 5 a ）. 胆管空腸吻合部に 縦切開を加え，㓔痕組織に強固に埋没していた EMS のステントメッシュを丁寧に肝側に向かって全て除去 した。ささらに胆管空腸吻合部とともにその上流側の肥 厚した胆管（図 5 b) を切除し, 左右肝管合流部直下 にて胆管空腸再吻合術を行い, 前区域胆管・後区域胆 管・左肝管へそれぞれ RTBD ステントチューブ（径 $3.5 \mathrm{~mm}$ )を留置した（図５ｃ）.

術後経過：術後はほほ順調に経過し, 術後第21病日 目にRTBD ステントチューブ留置のまま退院となっ た.外来での経過は順調で, 術後約 6 力月にあたる2002 年 3 月にステントチューブを抜去した。術後 17 月現 在，全く胆管炎症状は認めず経過は良好である。

\section{考察}

良性胆道狭穾には胆蓑摘出後の胆管狭窄，胆管吻合 後の狭窄, 肝内結石症による胆管狭窄, 慢性膵炎によ る胆管狭窄，硬化性胆管炎や外傷による胆管狭窄など が含まれるが，その $90 \%$ 以上が外科的処置に伴う医原

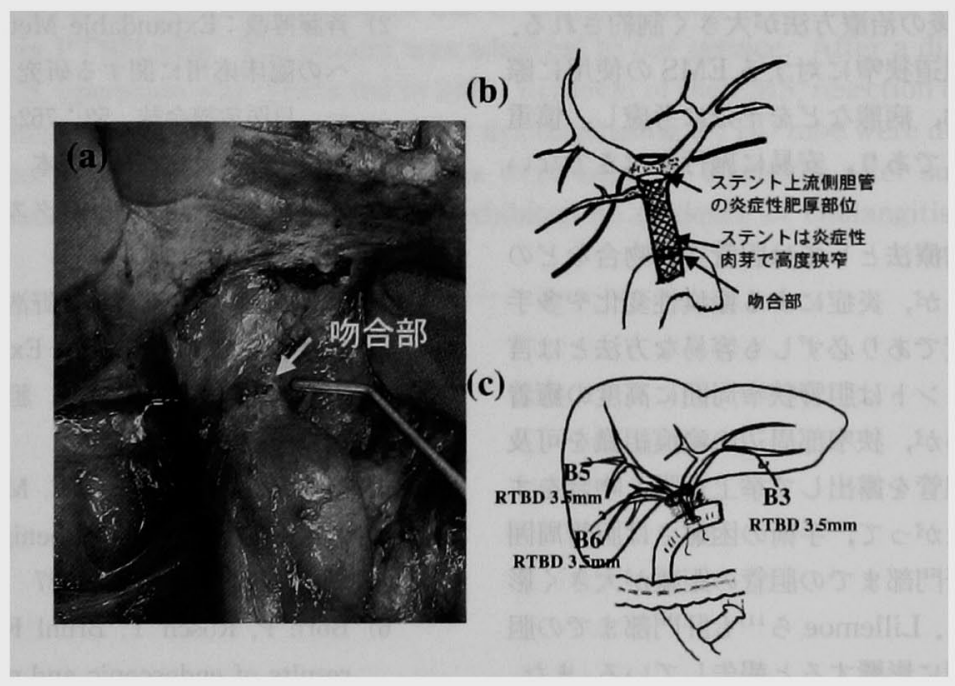

図 5 手術所見：a )肝門部を中心に痹着が高度であったが, 胆管空腸 吻合部 (矢印) を露出すると胆管は炎症性に肥厚し EMS の弾性を触 知した， b ) ステント内腔は炎症性肉芽により高度に狭窄し，その上 流側の肝門部胆管まで胆管壁の肥厚を認めた， c ) EMS を除去後, 胆管空腸吻合部とその肝側の肥厚した胆管を切除し, 肝門部胆管空 腸再吻合術を行い，前区域胆管・後区域胆管・左肝管へそれぞれ RTBD ステントチューブ（径3.5mm）を留圈した. 
性狭窄であると報告されている5!。これらの治療には 保存的療法と外科的療法が挙げられる, 保存的療法に はバルーン㹡張術やチューブステント留置法などがあ $\eta^{6)}$, バルーン㹡張術は70〜90\%の成功率と報告(27)8》 れているものの, 強固な洀痕のため十分な拡張が得ら れない症例，一時的に拡張が得られても再狭窄をきた す症例も少なからす存在する。このような症例に対し ては,チューブステントの長期留置が必要とされるが, 定期的なチュープの交換などのため長期間にわたる患 者の外来通院を要することが多い9．また，最近では interventional radiologyの向上により悪性胆道狭窄 に対してEMSの留置は確立したものとなったが，良 性胆道狭䂟に対する適応については未だ問題が多いと される，つまり，良性狭窄では長期の予後が見込まれ るため, 長期的な合併症としてのステント閉塞, すな わちワイヤー間隙抢よび EMS 両端での粘膜過形成に よる再閉塞, sludge, 結石の形成などが大きな問題とな る2). 植田ら ${ }^{3)}$ の報告によると良性狭窄10例に対しての EMS 留置後の開存率は24，36力月でそれそれ $38.5 \% ，$ $23.1 \%$ ありり，またDumonceau ら ${ }^{10}$ の良性狭窄 6 例 の報告では12，36力月の開存率はそれぞれ33\%，17\% であり，決して満足な結果とは言い難い。さらに，一 度留置されたEMS は再狭窄した際に手術以外に回収 が困難とされその後の治療方法が大きく制約される. したがって，良性胆道狭窄に対する EMSの使用に際 しては, 患者の年齡, 病態などを十分に考慮し, 慎重 に適応を決定すべきであり，安易に施行すべきでない と考える。

一方では，外科的療法としては胆管空腸吻合などの 胆道再建が行われるが，炎症による䖰痕性変化や多手 術による痹着が高度であり必ずしも容易な方法とは言 い難い. 手術のポイントは胆管狭罡周囲に高度の應着 を認めることが多いが，㹟窄部周辺の痗痕組織を可及 的に摘除し，健常胆管を露出して挙上空腸と吻合をす ることである。したがって，手術の困難さは胆管周囲 の痗痕化の程度と肝門部までの胆管の距離が大きく影 響すると考えられる. Lillemoe ら ${ }^{11}$ も肝門部までの胆 管の距離が術後成績に影響すると報告している。また, 必ず吻合部にステントチューブを留置し，再狭窄が奬 念される際には術後瘕痕収縮がおさまるまで最低 3

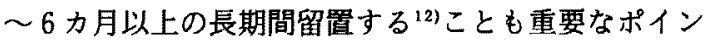
トとわれわれは考えている。

良性胆道狭察は，繰り返す胆管炎加ら続発性胆汁性 肝硬変や敗血症などの重篤な合併症をきたす可能性が
あり，治療にあたっては保存的治療に固執せずに胆道 再建を考虑すべきと考える．とくに今回報告した症例 のような若年患者の良性胆道狭窄に対する EMS 留置 後のステント閉塞に伴う繰り返す胆管炎に対しての治 療は, 保存的治療に固執せず, 胆道外科に熟練した施 設での外科的ステント除去および胆管空腸再吻合術を 積極的に選択すべきと考えられた，また，その際には 必ず詳細な胆道造影を行い, 狭窄部位を同定,さらに 肝門部胆管の分岐形態を十分に把握するとともに胆管 造影像にて不整な狭窄があれば癌の合併の有無を PTCS 下生検にて確実に診断することも忘れてはな らないと考える。

\section{結語}

良性胆道狭窄に対してEMS が留置され，その7年 後に炎症性肉芽によるステント閉塞をきたした症例に 対し外科的にステントを除去し胆管空腸吻合部ととも にその上流側の肥厚した胆管を切除し，肝門部胆管空 腸吻合術を行った症例を経験したので報告するととも に若干の文献的考察を加えた。

\section{文 献}

1）小川 毫, 清水一夫, 佐藤信紘他：金属ステント (metallic stent) を用いた胆道内瘦術の治療成續 々限界. 日臨 $54: 526-535,1997$

2) 斉藤博哉：Expandable Metallic Stent 9 胆道系 への臨床応用に関する研究一第 1 編 初期成績 一。目医放線会誌 $52: 762-773,1995$

3）植田俊夫, 大島 進, 岡本 健他: 胆道閉塞に対 する経皮経肝的メタリックステント．臨外 52 ： 1415-1420, 1997

4）安井智明，山中若樹，神野浩樹他：胆管空腸吻合 術後狭窄に対するSelf-Expandable Metallic Stent 留㯰の臨床的検討. 胆道 $11: 397-402$, 1997

5) Moore AV, Illescas FF, Mills SR, et al:Percutaneus dilatation of benign strictures. Radiology $163: 625-628,1987$

6) Born $P$, Rosch $T$, Bruhl $K$, et al: Long-term results of endoscopic and percutaneus transhepatic treatment of benign biliary strictures. Endoscopy $31: 725-731,1999$

7) Citron SJ, Martin LG: Benign biliary strictures : treatment with percutaneous cholangioplasty. Radiology 178: 339-341, 1991

8) Trambert JJ, Bron KM, Zajko AB, et al : Per- 
cutaneous transhepatic balloon dilatation of benign biliary strictures. Am J Roentgenol $149: 945-948,1987$

9）小松夈二, 清末一路, 松本俊郎他：胆管空腸吻合 術後の吻合部胆管狭窄に対するInterventional Radiology。胆と膵 $17: 1043-1048 ， 1996$

10) Dumonceau JM, Deviere J, Delhaye M, et al: Plastic and metal stents for postoperative benign bile duct strictures: the best and the worst. Gastrointest Endosc $47: 8-17,1998$

11) Lillemoe KD, Martin SA, Cameron JL, et al : Major bile duct injuries during laparoscopic cholecystectomy. Follow-up after combined surgical and radiological management. Ann Surg $225: 459-471,1997$

12）田中淳一, 梅澤昭子, 小山研二：術後胆管狭管. 臨外 $47: 345-351,1992$

\title{
A CASE OF SURGICAL TREATMENT FOR OCCLUSION OF BILIARY EXPANDABLE METALLIC STENT PLACED FOR BENIGN STRICTURE OF CHOLEDOCHOJEJUNOSTOMY AFTER EXTRAHEPATIC BILE DUCT RESECTION
}

\author{
Hiroaki SHIMIZU, Dan TAKEUCHI, Hiroshi ITO, \\ Fumio KIMURA, Akira TOGAWA and Masaru MIYAZAKI \\ Department of General Surgery, Graduate School of Medicine, Chiba University
}

We report a case of surgical treatment for occlusion of a biliary expandable metallic stent placed for benign choledochojejunostomy stricture. A 48-year-old woman underwent bile duct resection with choledojejunostomy for congenital biliary dilation at another hospital in 1993. One year later, choledochojejunostomy was redone because of stenosis of the bilioenteric anastomosis, but stenosis developed again early after surgery. An expandable metallic stent (EMS) was placed in the anastomosis. After biliary endoprosthesis, the patient had recurrent episodes of cholangitis. Seven years later, the patient developed acute obstructive purulent cholangitis due to EMS occlusion at the hepatic hilus, according to cholangiography via PTBD tube. The patient was admitted to our service. After a diagnosis of benign stricture with PTCS, operation was conducted in 2001. Removal of the EMS, resection of the bilioenteric anastomosis with hepaticicojejunostomy, and biliary drainage using RTBD tube were done. The patient' s postoperative course was uneventful. Stent tubes were kept for 6 months after surgery to prevent restenosis. The outcome was excellent, and she exhibited no evidence of cholangitis after stent tube removal. 